\title{
Pengaruh Tatakelola Terhadap Nilai Perusahaan Perbankan: ROA Dan NPL Sebagai Mediasi
}

\author{
Lisa Dentika $^{1}$, Syamsul Ridjal ${ }^{2}$ dan La Ode Sumail ${ }^{3}$ \\ ${ }^{1}$ Mahasiswa Magister Manajemen STIEM Bongaya \\ ${ }^{2,3}$ Sekolah Tinggi Ilmu Ekonomi Makassar (STIEM) Bongaya \\ Email Address: \\ lisapans89@gmail.com; ridjalsyamsul@yahoo.com; odesumail@stiem-bongaya.ac.id
}

\begin{abstract}
This study attempts to investigate the effect of governance on firm value mediated by financial performance and risk of banking firms on the IDX. The sampling technique uses 46 saturated samples and data sources from the 2017-2020 financial statements so that the number of observations is 184 . This study finds that bank governance can encourage an increase in firm value. Governance has a positive effect on ROA but has a negative effect on NPL. ROA has a positive effect on PBV and NPL has a negative effect on PBV. Governance has a positive and significant effect on PBV mediated by ROA and governance has a negative and significant effect on PBV mediated by NPL. Therefore, the role of ROA and NPL as partial mediation (partial mediation).
\end{abstract}

Key Words: governance, NPL, ROA, PBV.

\begin{abstract}
Abstrak: Studi ini berusaha menginvestikasi pengaruh tatakelola terhadap niali perusahaan dimediasi kinerja keuangan dan risiko perusahaan perbankan di BEI. Teknik penarikan sampel menggunakan sampel jenu sebanyak 46 dan sumber data dari laporan keuangan periode 2017-2020 sehingga jumlah pengamatan sebanyak 184. Studi ini menemukan bahwa tatakelola bank dapat mendorong kenaikan nilai perusahaan. Tatakelola berpengaruh positif terhadap ROA tetapi berpengaruh negatif terhadap NPL. ROA berpengaruh positif terhadap PBV dan NPL berpengaruh negatif terhadap PBV. Tatakelola berpengaruh positif dan signifikan terhadap PBV dimediasi ROA dan tatakelola berpengaruh negatif dan signifikan terhadap PBV dimediasi NPL. Karenanya, peran ROA dan NPL sebagai mediasi sebagian (partial mediation).
\end{abstract}

Kata kunci: tatakelola, NPL, ROA, PBV.

\section{PENDAHULUAN}

Nilai perusahaan (Firm value) merupakan potret bahwa perusahaan telah dikelola dengan kemasan berkinerja sehingga direspon oleh investor dan harga saham menjadi seksi di pasar. Harga saham perusahaan adalah harga yang diterima oleh investor atau pasar. Oleh karena itu, besar kecilnya nilai perusahaan dicerminkan oleh harga saham. Untuk meningkatkan nilai perusahaan tentunya perusahaan harus mampu mengelola keuangan dan 
menjalankan operasional perusahaannya dengan baik. Tatakelola perusahaan akan mendorong nilai perusahaan.

Tatakelola perusahaan merupakan upaya pengelolaaan sumberdaya ekonomi yang mendorong kinerja khususnya kinerja keuangan. Sebab, tatakelola perusahaan yang baik akan menghasilkan kinerja keuangan yang baik yakni profitabilitas serta mengurangi tingkat risiko profil perusahaan berupa Non Performing Loan (NPL) dan akan berdampak pada nilai perusahaan. Sebaliknya, tatakelola perusahaan yang tidak baik akan menghasilkan kinerja keuangan yang buruk yakni profitabilitas rendah serta NPL tinggi sehingga berdampak pada penurunan nilai perusahaan. Faktanya, nilai perusahaan pada perusahaan perbankan di Indonesia menunjukkan kondisi harga saham yang sangat sulit untuk mencapai 2 kali melebihi nilai bukunya. Artinya, nilai perusahaan perbankan cenderung rendah atau belum sesuai harapan dimata investor dan pemegang saham (shareholder).

Banyak penelitian sebelumnya menunjukkan bahwa nilai perusahaan ditentukan oleh tatakelola perusahaan, kinerja keuangan, risiko profil perusahaan, tanggung jawab sosial, ukuran perusahaan, dan lain-lain (Dewanti et al., 2018; Safitri \& Hastutie, 2016; Sixpria et al., 2013). Karena banyaknya faktor yang mempengaruhi nilai perusahaan maka penelitian ini mencurigai bahwa faktor penting yang mempengaruhi besar kecilnya nilai perusahaan adalah tatakelola perusahaan. Karenanya, menarik untuk dilakukan penelitian.

Penelitian sebelumnya melaporkan tentang hubungan tatakelola perusahaan dengan nilai perusahaan akan tetapi masih ada perdebatan. Misalnya, (Dewanti et al., 2018) menemukan bahwa semakin baik tatakelola perusahaan semakin tinggi nilai perusahaan. Sementara, (Dinah \& Darsono, 2017) menemukan bahwa semakin baik tatakelola perusahaan semakin rendah nilai perusahaan. Kemudian, (Safitri \& Hastutie, 2016) menemukan bahwa tatakelola perusahaan tidak dapat berkontribusi terhadap nilai perusahaan. Dalam pandangan agency theory, bahwa sulitnya mencapai dua kali melebihi nilai buku menunjukkan adanya ketidakpuasan oleh pemegang saham. Hal ini terkesan manager perusahaan perbankan belum mampu mensejahterakan pemegang saham sehingga ada kecenderungan potensi konflik antara manager dan pemegang saham. Oleh karena itu, fakta tersebut menarik jika disorot dari kacamata agency theory.

Memperhatikan fenomena empiris atau fakta dan adanya variasi hasil penelitian sebelumnya, maka motivasi penelitian ini adalah: (1) Meletakkan variabel tatakelola sebagai variabel utama dalam menentukan besar kecilnya nilai perusahaan, (2) Karena ada variasi atau celah hasil penelitian maka penelitian ini meletakkan variabel profitabilitas dan risiko profil perusahaan sebagai variabel mediasi dengan tujuan untuk mengisi celah hasil penelitian sebelumnya. Karena profitabilitas merupakan indikasi bahwa perusahaan telah dikelola dengan baik sehingga dapat mendorong nilai perusahaan. Selanjutnya, risiko profil perusahaan yang rendah merupakan wujud bahwa perusahaan telah dikelola dengan baik sehingga menghasilkan nilai perusahaan yang baik. (3) Agency theory sebagai pisau analisis untuk membedah hubungan antar variabel. Oleh karena itu, tujuan studi ini adalah menginvestigasi pengaruh tatakelola terhadap nilai perusahaan dimediasi kinerja keuangan dan risiko perusahaan perbankan di BEI.

\section{KAJIAN TEORI}


Tatakelola dan nilai perusahaan: Tatakelola bank dapat dimaknai upaya menggerakan sumber daya bank agar menghasilkan kinerja khususnya kinerja keuangan dan dapat mendorong nilai perusahaan. Untuk menghadirkan tatakelola bank yang baik maka manajemen perlu menyusun sistem monitoring sebagai cara untuk mengukur dan mengontrol risiko perusahaan dan meyakinkan bahwa pengaplikasiannya apakah efektif atau tidak (Triyuwono et al., 2020). Dengan kata lain, tatakelola bank sebagai suatu sistem pengendalian internal bank untuk mengelola risiko, mengamankan aset bisnis serta menghasilkan profitabilitas. Tentunya tatakelola yang baik akan direspon pasar atau investor sehingga harga saham naik dan nilai perusahaan tinggi (Swarte et al., 2020). Sebaliknya, bank yang tidak dikelola dengan baik akan menurunkan nilai perusahaan.

Ada banyak pengukuran tatakelola bank. Penelitian ini cenderung menggunakan dewan komisaris sebagai alat ukur tatakelola bank. Dewan komisaris (Board composition/BC) berkomitmen untuk melaksanakan praktik tatakelola perusahaan yang baik dan transparan serta menerapkan prinsip-prinsip etika dan moral secara bersungguhsungguh. Terkait dengan komposisi dewan komisaris dijabarkan dalam Peraturan Otoritas Jasa Keuangan Nomor 55 /POJK.03/2016. Dalam Pasal 24 dijabarkan bahwa dewan komisaris wajib terdiri atas komisaris independen dan komisaris non independen. Tugasnya, senantiasa melakukan pengawasan dan memberikan masukan yang disampaikan baik melalui komite independen. Dewan komisaris beranggotakan para profesional yang berpengalaman dalam industri perbankan. Mereka telah memenuhi kriteria yaitu memiliki integritas, kompetensi dan reputasi keuangan yang memadai. Boleh jadi komisaris independen mirip dengan direktur non-eksekutif (Safitri \& Hastutie, 2016).

Komisaris independen atau direktur non-eksekutif sangat penting untuk pembentukan kebijakan yang strategis. (Triyuwono et al., 2020) menemukan bahwa komisaris independen digunakan sebagai mekanisme check and balance untuk memastikan kepentingan pemilik dan pemangku kepentingan lainnya. (Sixpria et al., 2013) menunjukkan bahwa komisaris independen atau direktur non-eksekutif memiliki peran yang signifikan dalam menjelaskan kinerja di bank komersial. Di sisi lain, (Safitri \& Hastutie, 2016) menunjukkan bahwa komisaris independen atau direktur non-eksekutif menekan perusahaan untuk inisiatif pengungkapan untuk tujuan legitimasi. Namun, hubungan negatif ditemukan antara proporsi komisaris independen atau direktur non-eksekutif dan kinerja. Safitri \& Hastutie, (2016) tidak menemukan hubungan yang signifikan antara proporsi komisaris independen atau direktur non-eksekutif dan kinerja di sektor perbankan. Dengan demikian, hipotesis yang diajukan adalah:

\section{H1: Tatakelola berhubungan negatif dan signifikan dengan nilai perusahaan.}

Tatakelola dan Profitabilitas: Profitabilitas dapat diartikan sebagai indikator atas kinerja keuangan bank. Kinerja keuangan terlahir dari upaya manajemen telah melakukan tatakelola dengan baik sehingga menghasilkan profitabilitas. Sebaliknya, jika tatakelola tidak dilakukan dengan baik dapat dipastikan tidak akan menghasilkan profitabilitas. Penilitian (Putra \& Nuzula, 2017); Qomariah et al., 2018) menemukan bahwa tatakelola dapat mendorong profitabilitas. Kemudian, penelitian (Apriliani \& Dewayanto, 2018); (Astuti et al., 2019); (Putra et al., 2019) bahwa tatakelola tidak dapat meningkatkan profitabilitas. Jadi hipotesis yaitu: 


\section{H2: Tatakelola berhubungan positif dan signifikan dengan profitabilitas.}

Tatakelola dan risiko profil perusahaan: Risiko profil perusahaan identik dengan Non Performing Loan (NPL). NPL sebagai alat ukur tentang kinerja bank dalam aspek pemberian kredit kepada debitur. Ketika bank mampu menekan NPL berarti tatakelola bank dilakukan dengan baik. Sebaliknya, NPL tinggi berarti tatakelola bank belum dilakukan dengan baik. Penelitian sebelumnya (Hapsari, 2018) menemukan bahwa tatakelola perusahaan memiliki hubungan negatif namun tidak signifikan dengan risiko profil perusahaan. Berbeda dengan penelitian dari (Swarte et al., 2020) bahwa tatakelola berpengaruh positif dan signifikan terhadap risiko profil perusahaan (NPL). Sementara, penelitian (Arifina, 2019) mengatakan bahwa tatakelola perusahaan tidak memiki hubungan dengan risiko profil perusahaan (NPL). Karena itu, hipotesis penelitian yakni:

\section{H3: Tatakelola berhubungan negatif dan signifikan dengan risiko profil perusahaan (NPL)}

Profitabilitas dan nilai perusahaan: Nilai perusahaan dicerminkan oleh harga saham. Ketika nilai perusahaan tinggi berarti harga saham tinggi. Sebaliknya, semakin rendah harga saham semakin rendah nilai perusahaan. Harga saham yang tinggi berarti pasar atau investor merespon secara positif karena perusahaan berhasil mencetak profitabilitas (ROA) yang tinggi. Ketika bank tidak mampu mencetak ROA dapat dipastikan pasar atau investor akan merespon negaatif sehingga harga saham rendah dan nilai perusahaan akan rendah pula. Beberapa penelitian sebelumnya seperti (Astuti et al., 2019); (Harningsih et al., 2019); (Mariani \& Suryani, 2018); (Mudjijah et al., 2019); (Sianturi, 2020) menyatakan bahwa semakin tinggi profitabilitas semakin tinggi nilai perusahaan. Jadi kesimpulan sementara adalah:

H4: Profitabilitas (ROA) berhubungan positif dan signifikan dengan nilai perusahaan.

Wajah bank yang bersinar adalah bank yang telah dikelola dengan baik akan menghasilkan profitabilitas (ROA) yang tinggi sehingga nilai perusahaan akan tinggi. Sebaliknya, bank yang gagal mengelolah asset produktif tidak akan mampu mencetak ROA sehingga nilai perusahaan rendah. Dengan demikian, hipotesis yang diajukan yaitu:

\section{H5: Tatakelola berpengaruh positif dan signifikan terhadap nilai dimediasi ROA.}

Risiko profit perusahaan (NPL) dan nilai perusahaan: Bank yang berkinerja baik adalah bank yang mampu menekan NPL. Sebaliknya, bank yang belum berkinerja baik adalah bank yang belum mampu menekan NPL. Kemampuan bank menekan NPL akan meningkatkan harga saham sehingga nilai perusahaan tinggi. Bank yang gagal menekan NPl akan berakibat pada penurunan harga saham sehingga nilai perusahan menurun pula. Oleh karena itu, NPL memiliki keterkaitan dengan nilai perusahan. Penelitian sebelumnya oleh (Agustina \& Satriya Candra Bondan., 2017); (Maimunah \& Fahtiani, 2019); (Prabawati et al., 2021) menemukakan bahwa semakin rendah NPL semakin tinggi nilai perusahaan. 
Sementara penelitian dari (Rahmadi, 2019); (Ristiani \& Santoso, 2017) menemukan bahwa nilai perusahaan tidak lagi ditentukan oleh NPL. Maka hipotesis yaitu:

H6: Risiko profil perusahaan (NPL) berpengaruh negatif dan signifikan terhadap nilai perusahaan.

Kemampuan bank mengelola sumberdaya keuangan yang potensial dapat dipastikan akan mampu menekan NPL sehingga mempengaruhi harga saham meningkat dan nilai perusahaan meningkat pula. Bagi bank yang gagal dalam mengelala asset produktif seperti pinjaman cenderung NPL meningkat sehingga mempengaruhi harga saham menjadi rendah dan nilai perusahaan rendah. Karena itu, semakin baik tatakelola bank semakin rendah NPL dan semakin tinggi nilai perusahaan. Lalu hipotesis yang diajukan adalah:

H7: Tatakelola berpengaruh negative dan signifikan terhadap nilai perusahaan dimediasi NPL.

\section{METODOLOGI}

Karena terbatasnya jumlah populasi maka seluruh perusahaan perbankan di Bursa Efek Indonesia dijadikan sampel (sampel jenu) sebanyak 46. Artinya seluruh jumlah populasi dijadikan sampel. Sumber daya diperoleh dari laporan keuangan periode 20172020 sehingga jumlah pengamatan sebanyak 184 dengan metode analisis regresi eviews.

Table 3. Deskripsi variabel dan pengukuran

\begin{tabular}{lll}
\hline Variabel & Pengukuran & Sumber \\
\hline Tatakelola(BC) & $\begin{array}{l}\text { Percentage of independent } \\
\text { directors on the Board }\end{array}$ & (Sixpria et al., 2013) \\
Nilai perusahaan & PBV & (Maimunah \& Fahtiani, \\
& Laba bersih dibagi total asset x & (Ristiani \& Santoso, 2017) \\
Profitabilitas (ROA) & $100 \%$ & \\
& Kredit bermasalah dibagi kredit & (Arifina, 2019) \\
NPL & yang disalurkan x 100\% & \\
$\beta_{1,} \beta_{2,} \beta_{3,} \beta_{4}, \beta_{5}$, & Koefisien regresi & \\
Keterangan: Penggunaan pengukuran & sesuai dengan kondisi objektif pada bank konvensional dan bank \\
syariah & & \\
\hline Sumber: beberapa jurnal & &
\end{tabular}

\section{HASIL PENELITIAN}

Uji asumsim. Penelitian ini hanya melakukan Uji Normalitas (One sample KolomogrovSmirnov) dengan melihat tingkat signifikansi 5\%. Hasil pengujian menunjukan bahwa data berdistribusi normal karana nilai probabilitas $>0.05$ atau $0.4663>0.05$, seperti Gambar berikut ini. 


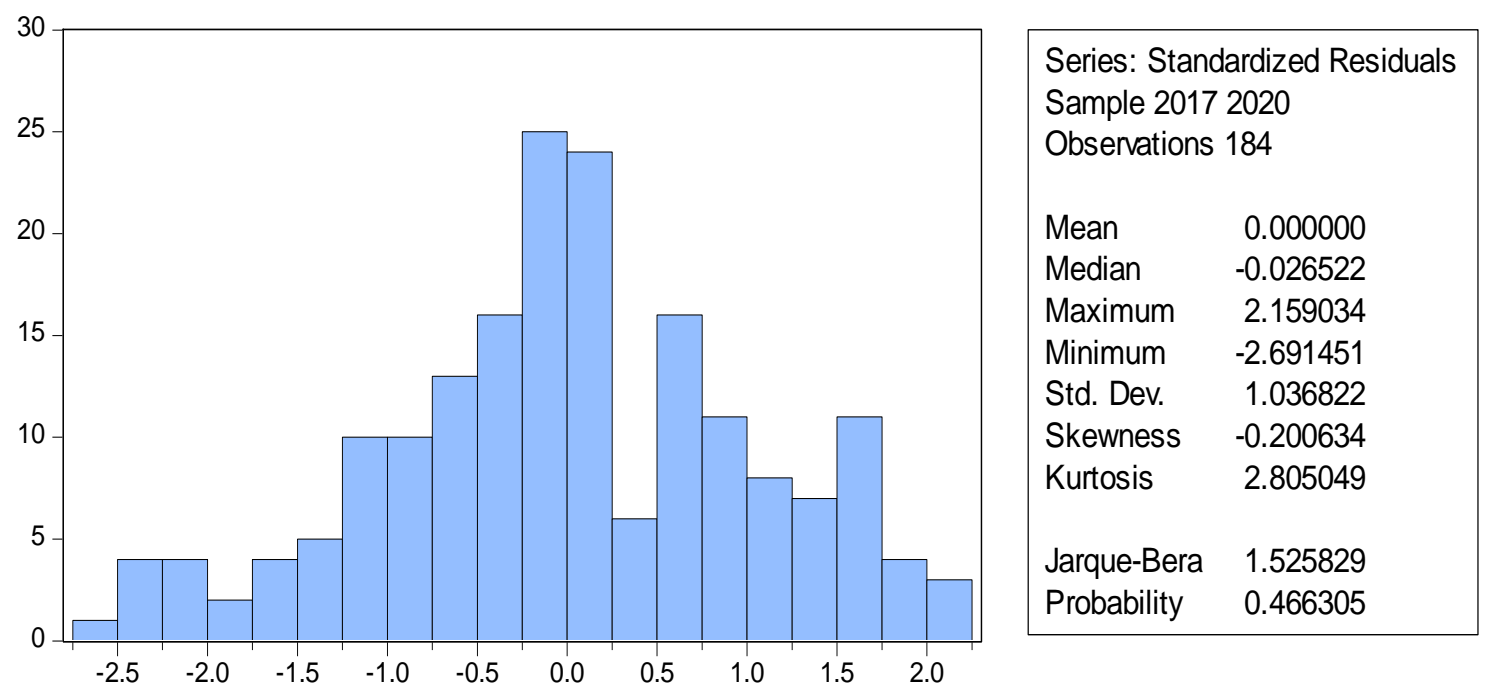

Gambar 1. Distribusi Normal

Analisis deskriptif. Penelitian ini hanya focus pada tingkat rata-rata (mean), maksimum, minimum dan standar deviasi. Hal ini merupakan bagian dari analisis deksriptif statistik.

Tabel 1. Kinerja Keuangan Bank

\begin{tabular}{lcccc}
\hline & Nilai Perusahaan & Tatakelola & Profitabilitas & NPL \\
\hline Mean & 1.4545 & 3.9268 & 0.3699 & 0.0443 \\
Median & 0.9838 & 3.9823 & 0.3100 & 0.0324 \\
Maximum & 4.5342 & 5.0001 & 0.6800 & 0.5422 \\
Minimum & 0.1231 & 3.2314 & 0.0500 & 0.0122 \\
Std. Dev. & 1.3820 & 0.5897 & 0.2506 & 0.0836 \\
\hline
\end{tabular}

Sumber: data dioleh 2021

PBV digunakan untuk mengukur mengukur nilai perusahaan. Nilai perusahan akan baik ketika nilai PBV diatas 1 atau PBV>1 dimana PBV menunjukkan bahwa nilai pasar saham lebih besar dari nilai buku (dikutip dari Maimunah \& Fahtiani, 2019). Rata-rata nilai perusahaan (PBV) adalah 1.4545. Artinya, $\mathrm{PBV}>1$ sehingga nilai perusahaan cukup tinggi mendekati 2. Investor akan tertarik membeli saham yang memiliki nilai PBV diatas 1 karena akan memberikan return yang tinggi. Kemudian, beberapa perusahaan ada yang memiliki PBV diatas rata-rata atau maksimum sebesar 4.5342 dan ada pula dibawah rata-rata atau minimum sebesar 0.1231. Informasi data ini dideskripsikan diterima karena standar deviasi dibawah nilai rata-rata sebesar 1.3820 .

Tatakelola perusahaan di proksikan oleh dewan komisaris. Peran dewan komisaris akan mencerminkan tatakelola bank. Ketika peran menunjukan $>1,5 \%$ dinyatakan sangat sehat, $1,25 \%-1,5 \%$ dinyatakan sehat, $0,5 \%-1,25 \%$ (cukup), $0,5 \%-1,25 \%$ (kurang sehat) dan $\leq 0 \%$ (tidak sehat). Rata-rata peran dewan komisaris sebesar 3.9268. Artinya, sangat sehat atau sangat baik dalam mengelola bank karena diatas $>1,5 \%$. Beberapa perusahaan ada yang menampilkan tatakelola sangat tinggi dengan nilai maksimum sebesar 5.0001. Dan ada pula yang menampilkan tatakelola dengan nilai minimum sebesar 3.2314. Informasi 
tentang tatakelola layak dideskripsikan karena standar deviasi dibawah nilai rata-rata sebesar 0.5897.

Rata-rata ROA sebesar 0.3699. Artinya, perusahaan perbankan mampu menghasilkan laba rata-rata 36,99\%. Tingkat maksimum ROA sebesar 0.6800 atau 68,00\%. Dan tingkat minimum ROA sebesar 0.0500 atau 5,00\%. Informasi tentang ROA layak dideskripsikan karena standar deviasi dibawah nilai rata-rata sebesar 0.2506 . Kemudian, rata- rata NPL sebesar 0.0443 atau 4,43\%. Artinya, tingkat risiko profil perusahaan masih dibawah toleransi karena nilai NPL dibawah 5\%. Nilai maksimum NPL sebesar 0.5422 atau 54,22\%. Artinya, ada beberapa perusahaan bank yang mengalami NPL tidak sehat karena diatas batas toleransi 5\%. Ada pula bank yang memiliki NPL minimum sebesar 0.0122 atau $1,22 \%$. Informasi tentang NPL layak dideskripsikan karena standar deviasi dibawah nilai rata-rata sebesar 0.0836 .

Analisis korelasi. Koefisien korelasi adalah ukuran tingkat hubungan linier antara dua atau lebih variabel. Korelasi positif antara tatakelola dan nilai perusahaan $(p<0.05)$. Tatakelola berkorelasi positif dengan profitabilitas $(\mathrm{p}<0.05)$. Tatakelola berkorelasi negatif dengan risiko profil perusahaan $(\mathrm{p}<0.05)$. Profitabilitas berkorelasi positif dengan nilai perusahaan $(\mathrm{p}<0.05)$ dan risiko profil perusahaan berkorelasi negatif dengan nilai perusahaan $(\mathrm{p}<0.05)$.

Tabel 2. Hubungan Korelasi Antar Variable

\begin{tabular}{ccccc}
\hline & FV & BC & PROF & NPL \\
\hline FV & 1 & & & \\
BC & $0.0912^{* * *}$ & 1 & & \\
PROF & $0.2737 * * *$ & $0.0131^{* * *}$ & 1 & \\
NPL & $-0.0684^{* * *}$ & $-0.0373^{* * *}$ & $-0.0453^{* * *}$ & 1 \\
\hline Sumber: hasil penelitian 2021 & & & &
\end{tabular}

Uji pemilihan model. Penelitian ini telah melakukan simulasi model yakni Common Effect Model (CEM), Fixed Effect Model (FEM) dan Random Effect Model (REM). Dari beberapa simulasi tersebut maka dilakukan uji pemilihan model melalui Uji Chow Chow test, Uji Hausman, dan Uji Lagrange Multiplier. Berdarkan Chow test maka model yang dikehendaki adalah model Fixed Effet karena nilai probabilitas $<0.05$ yakni $0.0001<0.05$.

Setiap hubungan menghasilkan model yang baik diukur dengan Adjusted R-squared sehingga layak dilakukan analisis. Pertama, hubungan langsung: Hubungan tatakelola dengan nilai perusahaan sebesar 0.4479 atau 44.79\%. Hubungan tatakelola dengan profitabilitas sebesar 0.4843 atau $48.43 \%$. Hubungan tatakelola dengan risiko profil perusahaan sebesar 0.3402 atau $34.02 \%$. Hubungan profitabilitas dengan nilai perusahaan sebesar 0.4275 atau $42.75 \%$. Hubungan risiko profil perusahaan dengan nilai perusahaan sebesar 0.4279 atau $42.79 \%$. Kedua, hubungan mediasi. Hubungan tatakelola dengan nilai 
perusahaan dimediasi profitabilitas dan risiko profil perusahaan sebesar 0.4701 atau $47.01 \%$. Kesemua antar hubungan variabel diasumsikan $100 \%$ sehingga sisanya menjadi model penelitian yang akan datang.

Pengujian Hipotesis. Untuk mengetahui tingkat signifikasi yakni membandingkan $p$ value dengan alpha 0.05 , atau membandingkan $\mathrm{t}$ statistic dengan $\mathrm{t}$ table. Jika $p$ value $<0.05$ atau $\mathrm{t}$ statistic $>t$ table maka dikatakan signifikan. Sebaliknya, jika p value $>0.05$ atau t statistic < t student (1.96) dikatakan tidak signifikan. Kemudian, dalam penelitian ini terdapat hubungan positif (searah) dan hubungan negative (tidak searah).

Tabel 3. Koefisien jalur

\begin{tabular}{lllll}
\hline Hubungan antar variabel & $\begin{array}{l}\text { Koefisien } \\
\text { jalur }\end{array}$ & t-Statistic & Prob. & Keterangan \\
\hline $\begin{array}{l}\text { Tanpa mediasi: } \\
\text { Tatakelola (BC) } \rightarrow \text { nilai perusahaan (PBV) }\end{array}$ & 0.3288 & -2.9286 & 0.0358 & $\begin{array}{l}\text { Signifikan } \\
\text { Tatakelola (BC) } \rightarrow \text { profitabilitas (ROA) }\end{array}$ \\
$\begin{array}{l}\text { Tatakelola (BC) } \rightarrow \text { risiko profil (NPL) } \\
\text { Profitabilitas (ROA) } \rightarrow \text { nilai perusahaan }\end{array}$ & -0.2193 & -3.6891 & 0.0019 & $\begin{array}{l}\text { Signifikan } \\
(P B V)\end{array}$ \\
$\begin{array}{l}\text { Risiko profil (NPL) } \rightarrow \text { nilai perusahaan } \\
(\text { PBV) }\end{array}$ & -0.1535 & -2.3953 & 0.0033 & Signifikan \\
$\begin{array}{l}\text { Dengan mediasi: } \\
\text { Tatakelola } \rightarrow \text { nilai perusahaan }\end{array}$ & 0.2007 & 2.2591 & 0.0060 & Signifikan \\
\hline
\end{tabular}

Sumber: Hasil penelitian 2021

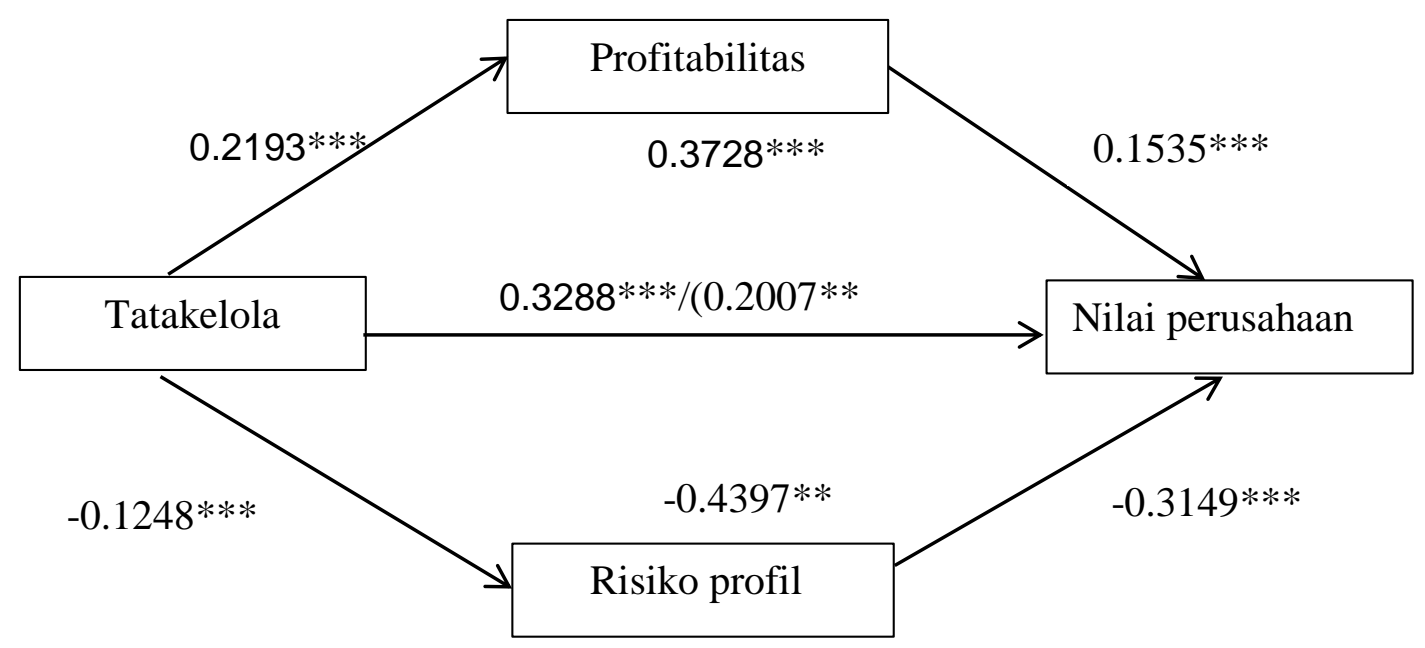

Gambar 2. Model hasil penelitian 
Keterangan: $* * 0.05$ (signifikan); ***0.01 (signifikan tinggi) dan nilai koefisien dalam kurung adalah setelah mediasi.

Hasil pengujian peran mediasi menunjukkan bahwa tatakelola perusahaan berhubungan positif dan signifikan dengan nilai perusahaan dimediasi profitabilitas. Nilai koefisien sebesar 0.3728 atau positif dan nilai probabilitas sebesar 0.0002 atau signifikan, karena $\mathrm{p}$ value $<0.05$ atau $0.0002<0.05$. Artinya, semakin baik tatakelola perusahaan semakin tinggi profitabilitas dan semakin tinggi nilai perusahaan. Kemudian, peran NPL sebagai mediasi menunjukkan bahwa tatakelola perusahaan berpengaruh negatif dan signifikan terhadap nilai perusahaan. Nilai koefisien sebesar -0.4397 atau positif dan nilai probabilitas sebesar 0.0120 atau signifikan, karena p value $<0.05$ atau $0.0120<0.05$. Artinya, semakin baik tatakelola perusahaan semakin rendah risiko profil perusahaan dan semakin tinggi nilai perusahaan. Berdasarkan analisis mediasi maka sifat mediasi dalam penelitian ini dapat dikatakan sebagai variabel mediasi sebagian (partial mediation).

\section{PEMBAHASAN}

Studi ini menemukan bahwa tatakelola perusahaan berpengaruh positif dan signifikan terhadap nilai perusahaan. Hal ini menunjukan bahwa tatakelola baik maka nilai perusahaan baik pula. Dari hasil penelitian, menemukan bahwa tatakelola perusahaan di proksikan oleh dewan komisaris adalah cukup baik. Artinya, dewan komisaris berkomitmen untuk melaksanakan praktik tatakelola perusahaan yang baik dan transparan serta menerapkan prinsip-prinsip etika dan moral secara bersungguh-sungguh sehingga pemangku kepetingan termasuk investor merespon positif dan perusahaan perbakan mampu mendorong nilai perusahaan.

Terbukti bahwa rata-rata peran dewan komisaris sebesar 3.9268. Artinya, sangat sehat atau sangat baik dalam mengelola bank karena diatas $>1,5 \%$. Oleh karena itu, tatakelola yang baik dapat mendorong nilai perusahaan. Penelitian ini menemukan rata-rata nilai perusahaan (PBV) sebesar 1.4545. Artinya, PBV>1 sehingga nilai perusahaan cukup tinggi mendekati 2. Investor akan tertarik membeli saham yang memiliki nilai PBV diatas 1 karena akan memberikan return yang tinggi. Selain itu, investor memiliki keyakinan bahwa bank telah dikelola tatakelola dengan baik sehingga pasar merespon positif maka harga saham tinggi. Kenaikan harga saham akan meningkatkan nilai perusahaan. Kemudian, beberapa perusahaan ada yang memiliki PBV diatas rata-rata atau maksimum sebesar 4.5342 dan ada pula dibawah rata-rata atau minimum sebesar 0.1231 .

Penelitian ini mendukung hasil penelitian (Dewanti et al., 2018) menemukan bahwa semakin baik tatakelola perusahaan semakin tinggi nilai perusahaan. Sementara, penelitian ini tidak mendukung penelitian (Dinah \& Darsono, 2017) menemukan bahwa tatakelola perusahaan berhubungan negatif dan signifikan dengan nilai perusahaan. Artinya, semakin baik tatakelola perusahaan semakin rendah nilai perusahaan. Kemudian, tidak mendukung pula penelitian (Safitri \& Hastutie, 2016) menemukan bahwa tatakelola perusahaan tidak dapat berkontribusi terhadap nilai perusahaan. Ketika bank dikelola dengan baik serta menghasilkan nilai perusahaan yang tinggi maka dapat dipastikan tidak terjadi konflik kepentingan. Dalam pandangan agency theory bahwa tatakelola yang baik dan dapat mendorong nilai perusahaan akan tidak melahirkan konflik kepentingan. 
Studi ini menemukan bahwa tatakelola berhubungan positif dan signifikan dengan profitabilitas. Hal ini dapat dimaknai bahwa semakin baik tatakelola bank semakin tinggi profitabilitas bank. Tatakelola perusahaan di proksikan oleh dewan komisaris yang memiliki komitmen untuk melaksanakan praktik tatakelola bank yang baik dan transparan serta menerapkan prinsip-prinsip etika dan moral secara bersungguh-sungguh maka menghasilkan kinerja keuangan berupa profitabilitas. Dimana rata-rata peran dewan komisaris sebesar 3.9268 dalam mengelola bank. Artinya, sangat sehat atau sangat baik dalam mengelola bank karena diatas $>1,5 \%$. Dengan demikian, tatakelola mampu mendorong profitabilitas.

ROA adalah proksi bahwa perusahaan dapat menghasilkan laba. Penelitian ini menemukan rata-rata profitabilitas atau ROA sebesar 0.3699. Artinya, perusahaan perbankan mampu menghasilkan laba rata-rata 36.99\%. Penelitian ini mendukung penelitian sebelumnya. Misalnya, (Putra \& Nuzula, 2017); Qomariah et al., 2018) meemukan bahwa tatakelola dapat mendorong profitabilitas. Sementara, penelitian ini tidak mendukung penelitian (Apriliani \& Dewayanto, 2018); (Astuti et al., 2019); (Putra et al., 2019) bahwa profitabilitas tidak dapat meningkatkan profitabilitas. Praktik tatakelola yang baik akan menghasilkan kinerja keuangan berupa profitabilitas. Dalam pandangan agency theory bahwa ketika bank dikelola dengan baik akan menghasilkan kinerja keuangan berupa profitabilitas yang tinggi sehinggga tidak akan terjadi benturan kepentingan antara manajemen dan pemilik saham.

Studi ini menemukan bahwa tatakelola bank berhubungan negatif dengan risiko profil perusahaan (NPL). Artinya, tatakelola perusahaan di proksikan oleh dewan komisaris memiliki komitmen tinggi untuk melaksanakan praktik tatakelola perusahaan yang baik dan transparan serta menerapkan prinsip-prinsip etika dan moral secara bersungguh-sungguh sehingga mampu menekan risiko profil perusahaan berupa Non Perfoming Loan (NPL). Terbukti bahwa rata-rata peran dewan komisaris sebesar 3.9268. Artinya, sangat sehat atau sangat baik dalam mengelola bank karena diatas $>1,5 \%$. Oleh karena itu, tatakelola yang baik dapat menekan risiko profil perusahaan (NPL).

NPL adalah rasio yang menunjukan kredit bermasalah sebagai akibat ketidakmampuan manajemen mengelola dengan baik pinjaman kepada nasabah diikuti dengan ketidakmampuan nasabah mengembalikan jumlah pinjaman yang diterima dari bank. Hasil penelitian menemukan bahwa rata-rata NPL sebesar 0.0443 atau 4,43\%. Artinya, tingkat risiko profil perusahaan masih dibawah toleransi karena nilai NPL dibawah 5\%. Dengan demikian, tatakelola bank yang baik dapat menurunkan NPL. Studi ini mendukung studi (Hapsari, 2018) menemukan bahwa tatakelola perusahaan berpengaruh negatif terhadap risiko profil perusahaan. Studi ini berbeda hasil dengan (Swarte et al., 2020) bahwa tatakelola berpengaruh positif dan signifikan terhadap risiko profil perusahaan (NPL). Sementara, penelitian (Arifina, 2019) mengatakan bahwa tatakelola perusahaan tidak memiki hubungan dengan risiko profil perusahaan (NPL). Praktik tatakelola yang baik akan dapat menekan risiko profil perusahaan (NPL). Dalam pandangan agency theory bahwa ketika bank dikelola dengan baik akan dapat menekan risiko profil perusahaan (NPL) sehingga antara manajemen dan pemegang saham tidak akan ada benturan kepentingan diantara mereka.

Studi ini menemukan bahwa antara profitabilitas dan nilai perusahaan memiliki hubungan positif dan signifikan. Artinya, semakin tinggi profitabilitas semakin tinggi nilai 
perusahaan. Profitabilitas sebagai intrumen untuk mengukur kinerja keuangan. Ketika kinerja keuangan baik, pasar akan merespon positif dan harga saham menjadi menarik di pasar sehingga mendorong nilai perusahaan. Oleh karena itu, bank yang memiliki kinerja keuangan berupa profitabilitas yang baik akan meningkatkan harga saham sehingga nilai perusahaan menjadi tinggi. Terbukti hasil penelitian menunjukan bahwa rata-rata profitabilitas (ROA) sebesar 0.3699. Artinya, perusahaan perbankan mampu menghasilkan laba rata-rata $36.99 \%$. Kinerja keuangan ROA dapat mendorong nilai perusahaan. Sebagai bukti bahwa rata-rata nilai perusahaan (PBV) adalah 1.4545. Artinya, $\mathrm{PBV}>1$ sehingga nilai perusahaan cukup tinggi mendekati 2 . Investor akan tertarik membeli saham yang memiliki nilai PBV diatas 1 karena akan memberikan return yang tinggi. Penelitian ini mendukung penelitian sebelumnya. Misalnya, (Astuti et al., 2019); (Harningsih et al., 2019); (Mariani \& Suryani, 2018); (Mudjijah et al., 2019); (Sianturi, 2020) menyatakan bahwa profitabilitas dapat mendorong nilai perusahaan. Dalam pandangan agency theory bahwa ketika bank yang memiliki kinerja keuangan berupa profitabilitas (ROA) dengan baik akan dapat mendorong harga saham dan nilai perusahaan tinggi sehingga antara manajemen dan pemegang saham tidak terjadi benturan kepentingan.

Penelitian ini menemukan bahwa tatakelola perusahaan berhubungan positif dan signifikan dengan nilai perusahaan dimediasi dengan profitabilitas. Artinya, tatakelola baik maka profitabilitas (ROA) menjadi baik sehingga dapat mendorong nilai perusahaan menjadi baik pula. Dari hasil penelitian, menemukan bahwa tatakelola perusahaan di proksikan oleh dewan komisaris dan mereka berkomitmen untuk melaksanakan praktik tata kelola perusahaan yang baik dan transparan serta menerapkan prinsip-prinsip etika dan moral secara bersungguh-sungguh sehingga pemangku kepetingan termasuk investor merespon positif dan perusahaan perbankan sehingga mampu menciptakan laba serta meningkatkan harga saham perusahaan.

Terbukti bahwa rata-rata peran dewan komisaris sebesar 3.9268. Artinya, sangat sehat atau sangat baik dalam mengelola bank karena diatas $>1,5 \%$. Oleh karena itu, tatakelola yang baik dapat mendorong profitabilitas dan berdampak pada nilai perusahaan. Penelitian ini menemukan rata-rata nilai perusahaan (PBV) sebesar 1.4545. Artinya, PBV $>1$ sehingga nilai perusahaan cukup tinggi mendekati 2 . Investor akan tertarik membeli saham yang memiliki nilai PBV diatas 1 karena akan memberikan return yang tinggi. Kemudian, peran profitabilitas sangat tinggi dalam memediasi hubungan antara tatakelola dan nilai perusahaan. Terbukti bahwa rata-rata peran profitabilitas (ROA) sebesar 0.3699. Artinya, perusahaan perbankan mampu menghasilkan laba rata-rata 36.99\%. Kinerja keuangan ROA dapat mendorong nilai perusahaan. Sebagai bukti bahwa rata-rata nilai perusahaan (PBV) adalah 1.4545. Artinya, PBV>1 sehingga nilai perusahaan cukup tinggi mendekati 2. Investor akan tertarik membeli saham yang memiliki nilai PBV diatas 1 karena akan memberikan return yang tinggi. Penelitian ini mendukung penelitian (Putra \& Nuzula, 2017); Qomariah et al., 2018) menemukan bahwa tatakelola dapat mendorong profitabilitas. Serta penelitian dari (Astuti et al., 2019); (Harningsih et al., 2019); (Mariani \& Suryani, 2018); (Mudjijah et al., 2019); (Sianturi, 2020) menyatakan bahwa profitabilitas dapat berkontribusi terhadap nilai perusahaan. Dalam pandangan agency theory bahwa ketika bank dikelola dengan sungguh-sungguh akan mencetak profitabilitas yang tinggi serta dapat mendorong harga saham dan nilai perusahaan tinggi sehingga tidak ada benturan kepentingan antara manajemen dan pemegang saham. Karenanya, dapat dinyatakan bahwa 
profitabilitas memiliki peran berarti adalam memediasi hubungan antara tatakelola dan nilai perusahaa sehingga profitabilitas dikatakan sebagai variabel mediasi sebagian (partial mediation).

Penelitian ini menemukan bahwa risiko profil perusahaan berhubungan negatif dan signifikan dengan nilai perusahaan. Artinya, risiko profil perusahaan (NPL) dapat ditekan akan menguatkan kinerja keuangan bank. Artinya, bank menunjukan bahwa kinerja keuangan dari aspek NPL rendah sehingga pasar akan merespon positif dan nilai saham menjadi tinggi. Sebaliknya, jika NPL terlalu tinggi akan berakibat pada rendahnya harga saham yang dapat menurunkan nilai perusahaan. Penelitian ini mendukung penelitian sebelumnya oleh (Agustina \& Satriya Candra Bondan., 2017); (Maimunah \& Fahtiani, 2019); (Prabawati et al., 2021) menemukakan bahwa NPL berpengaruh negative dan signifikan terhadap nilai perusahaan. Sementara penelitian ini tidak mendukung penelitian dari (Rahmadi, 2019); (Ristiani \& Santoso, 2017) menemukan bahwa nilai perusahaan tidak ditentukan lagi oleh NPL. Dalam pandangan agency theory bahwa ketika bankmampu menekan risiko profil perrusahaan (NPL) maka akan dapat mendorong harga saham dan nilai perusahaan tinggi dan dapat dipastikan antara manajemen dan pemegang saham tidak terjadi benturan kepentingan.

Studi ini menemukan bahwa tatakelola perusahaan berhubungan negatif dan signifikan dengan nilai perusahaan dimediasi dengan risiko profil perusahaan (NPL). Hal ini menunjukan bahwa tatakelola baik dapat menekan risiko profil perusahaan berupa NPL sehingga pasar merespon positif, harga saham menjadi menarik dan dapat mendorong nilai perusahaan menjadi baik pula. Ada upaya besar dari dewan komisaris untuk merealisasikan komitmennya dalam menekan risiko profil perusahaan berupa NPL sehingga dapat mendorong nilai perusahaan. Sebaliknya, komitmen yang rendah akan meningkat NPL dan berdampak buruk pada nilai perusahaan.

Sebagai bukti bahwa rata-rata peran dewan komisaris sebesar 3.9268. Artinya, sangat sehat atau sangat baik dalam mengelola bank karena diatas $>1,5 \%$. Dengan demikian, tatakelola bank yang mumpuni dapat menurunkan NPL dan dapat mendorong nilai perusahaan. Peran NPL sangat besar dalam memediasi hubungan tatakelola dengan nilai perusahaan. Artinya, ada kontribusi berarti bahwa NPL rendah nilai perusahaan tinggi. Sebagai bukti bahwa rata-rata nilai perusahaan (PBV) adalah 1.4545. Artinya, PBV >1 sehingga nilai perusahaan cukup tinggi mendekati 2. Investor akan tertarik membeli saham yang memiliki nilai PBV diatas 1 karena akan memberikan return yang tinggi.

Studi ini mendukung temuan (Hapsari, 2018) menemukan bahwa tatakelola perusahaan berhubungan negative dan tidak signifikan dengan risiko profil perusahaan. Temuan studi ini berbeda dengan (Swarte et al., 2020) bahwa tatakelola berpengaruh positif dan signifikan terhadap risiko profil perusahaan (NPL). Ketika NPL rendah maka nilai perusahaan tinggi. Penelitian ini mendukung (Agustina \& Satriya Candra Bondan., 2017); (Maimunah \& Fahtiani, 2019); (Prabawati et al., 2021) menemukakan bahwa NPL berpengaruh negative dan signifikan terhadap nilai perusahaan. Sementara penelitian ini tidak mendukung penelitian dari (Rahmadi, 2019); (Ristiani \& Santoso, 2017) menemukan bahwa nilai perusahaan tidak lagi ditentukan oleh NPL. Dalam pandangan agency theory bahwa ketika bank dikelola dengan baik akan mampu menekan risiko profil perrusahaan (NPL) maka akan dapat mendorong harga saham dan nilai perusahaan tinggi sehingga antara manajemen dan pemegang saham mereka akan terhindar dari benturan kepentingan. Maka 
dapat dikatakan bahwa risiko profil perusahaan (NPL) memiliki peran berarti adalam memediasi hubungan antara tatakelola dan nilai perusahaa sehingga risiko profil perusahaan dikatakan sebagai variabel mediasi sebagian (partial mediation).

\section{KESIMPULAN}

Penelitian berusaha menginvestigasi pengaruh tatakelola terhadap nilai perusahaan dimediasi kinerja keuangan dan risiko perusahaan perbankan di BEI. Tatakelola bank berhubungan positif dan signifikan dengan nilai perusahaan (PBV) pada perbankan konvensional dan syariah. Selanjutnya, tatakelola bank berhubungan positif dan signifikan dengan profitabilitas (ROA) dan berhubungan negatif dan signifikan dengan risiko profil perusahaan (NPL). Kemudian, ROA berhubungan positif dan signifikan dengan nilai perusahaan. Sedangkan, NPL dapat ditekan sehingga mendorong nilai perusahaan. Tatakelola bank memiliki kontribusi berarti dalam mendorong nilai perusahaan (PBV) dimediasi ROA. Artinya, semakin baik tatakelola bank semakin tinggi ROA dan semakin tinggi PBV. Begitupula, tatakelola bank berpengaruh negative dan signifikan terhadap nilai perusahaan dimediasi NPL. Artinya, semakin baik tatakelola bank semakin rendah NPL dan semakin tinggi PBV.

Objek penelitian adalah gabungan bank konvesional dan Syariah maka penelitian kedepan perlu perlu memisahkan antara objek bank konvensional dan bank syariah. Selanjutnya, penelitian kedepan disarankan menggunakan proksi Tobins $Q$ atau price earning ratio (PER) dalam mengukur nilai perusahaan. Dan penelitian ini menemukan bahwa kebaikan model penelitian hanya sebesar 0.4701 atau $47.01 \%$, maka $52.99 \%$ dijelaskan oleh variabel lain sehingga menjadi peluang menambah variabel seperti ukuran perusahaan sebagai variabel mediasi.

\section{DAFTAR PUSTAKA}

Agustina, Chahya, R., Santosa, \& Awan. (2019). Pengaruh DAR, DER Dan Tata Kelola Perusahaan Terhadap Kinerja Keuangan Perusahaan Farmasi. Capital: Jurnal Ekonomi Dan Manajemen, 3(1), 16.

Agustina, L. M., \& Satriya Candra Bondan, (2017). Pengaruh Kesehatan Bank Dengan Menggunakan Profil Risiko, Tata Kelola Perusahaan, Rentabilitas, Dan Permodalan Terhadap Nilai Perusahaan (Studi pada Perusahaan Perbankan yang Terdaftar di Bursa Efek Indonesia Periode 2013-2016). 2(1), 103-112.

Apriliani, M. T., \& Dewayanto, T. (2018). Pengaruh tatakelola perusahaan dan ukuran perusahaan terhadap kinerja keuangan perusahaan artikel ilmiah. Diponegoro Journal of Accounting, 7(1), 1-10.

Arifina, Y. (2019). Peran Tata Kelola Perusahaan Dan Risiko Pelaporan Keuangan Dalam Pembentukan Komite Manajemen Risiko Yang Terpisah. Jurnal Akuntansi Bisnis, 15(2), 246.

Astuti, Haris, H., Oktavianus, R. A., \& Augustine, Y. (2019). Pengaruh Pengungkapan Corporate Social Responsibility Dan Kinerja Terhadap Nilai Perusahaan Dengan Tipe Industri Sebagai Variabel Moderasi. Jurnal Magister Akuntansi Trisakti, 5(2), 185.

Dewanti, Putri, Monica Paramita Ratna, Djajadikerta, \& Hamfri. (2018). Pengaruh Kinerja 
Keuangan dan Tata Kelola Perusahaan Terhadap Nilai Perusahaan pada Industri Telekomunikasi di Bursa Efek Indonesia. Jurnal Akuntansi Maranatha, 10(1), 98116.

Dinah, A. F., \& Darsono. (2017). Pengaruh Tata Kelola Perusahaan, Profitabilitas, Dan Penghindaran Pajak Terhadap Nilai Perusahaan. Diponegoro Journal of Accounting, 6(3), 1-15.

Dety Mulyanti, M. P. (2017). Manajemen Keuangan Perusahaan. Jurnal Ilmiah Akuntansi, $8,62-71$.

Hapsari, A. A. (2018). Pengaruh Struktur Kepemilikan Dan Tata Kelola Perusahaan Terhadap Pengungkapan Manajemen Risiko. Jurnal Muara Ilmu Ekonomi Dan Bisnis, 1(2), 22-34

Harningsih, S., Agustin, H., \& Setiawan, M. A. (2019). Pengaruh Kinerja Keuangan Terhadap Nilai Perusahaan DenHarningsih, S., Agustin, H., \& Setiawan, M. A. (2019). Pengaruh Kinerja Keuangan Terhadap Nilai Perusahaan Dengan Pengungkapan CSR Dan Kebijakan Dividen Sebagai Variabel Moderasi. Ranah Research Journ. Ranah Research Journal of Multidisciplinary Research and Development, 1(2), 199-209.

Lutfilah Amanti. (2018). Pengaruh Good Corporate Governance Terhadap Nilai Perusahaan dengan Pengungkapan Corporate Sosial Responsibility sebagai Variabel Pemoderasi (Studi Kasus Pada Perusahaan Rokok Yang Terdaftar Di BEI). Jurnal Akuntansi AKUNESA, 1, 21.

Maimunah, S., \& Fahtiani, T. (2019). Pengaruh Npl, Roa, Dan Car Terhadap Pbv Pada Bank Bumn. Jurnal Informasi, Perpajakan, Akuntansi, Dan Keuangan Publik, 14(1), 19.

Mariani, D., \& Suryani. (2018). Pengaruh Kinerja Keuangan Terhadap Nilai Perusahaan Dengan Kinerja Sosial Dan Kinerja Lingkungan Sebagai Variabel Moderator (Studi Empiris Pada Perusahaan Pertambangan dan Manufaktur yang Terdaftar di Bursa Efek Indonesia Tahun 2011 - 2015). Jurnal Akuntansi Dan Keuangan, 7(1), 59-78.

Mudjijah, Slamet, \& Zulvia Khalid, and D. A. S. A. (2019). Pengaruh Kinerja Keuangan dan Struktur Modal terhadap Nilai Perusahaan yang dimoderasi Variabel Ukuran Perusahaan. Jurnal Akuntansi Dan Keuangan, 8(1), 41-56.

Prabawati, Ni Putu Sita, Pradnyani, Abdi, N. D., \& Suciwati, D. P. (2021). Pengaruh RGEC (Risk Profile, Good Corporate Governance, Earnings, dan Capital) terhadap Nilai Perusahaan (Studi Kasus Perusahaan Perbankan di BEI 2016-2018). Jurnal Bisnis Dan Kewirausahaan, 17(1), 78-85.

Putra, A., \& Nuzula, N. (2017). Pengaruh Corporate Governance Terhadap Profitabilitas (Studi Pada Perusahaan Perbankan yang Terdaftar di Bursa Efek Indonesia Periode 2013-2015). Jurnal Administrasi Bisnis S1 Universitas Brawijaya, 47(1), 103-112.

Putra, Renaldi, Zakaria, Yoselin Klen Elia, Hidayat, Ariati, A., \& Adelina, Y. E. (2019). Pengaruh Penerapan Tata Kelola Perusahaan Terhadap Profitabilitas Perbankan di Indonesia. Studi Akuntansi Dan Keuangan Indonesia, 2(1), 98-123.

Putri, I., \& Suprasto H, B. (2016). Pengaruh Tanggung Jawab Sosial Perusahaan Dan Mekanisme Tata Kelola Perusahaan Terhadap Nilai Perusahaan. E-Jurnal Akuntansi, 15(1), 667-694.

Qomariah, Martini, N., Putu, N. N., Paramu, \& Hadi. (2018). Dampak Tata Kelola Perusahaan, Tanggung Jawab Sosial Perusahan Dan Intelectual Capital Terhadap 
Profitabilitas Perusahaan. Jurnal Sains Manajemen Dan Bisnis Indonesia, 8(1), 4761.

Rahmadi, Z. T. (2019). Pengaruh Net Interest Margin,Non Performing Loan Dan Capital Adequency Ratio Terhadap Nilai Perusahaan Dengan Tobin's Q Sebagai Indikator Pengukur Pada Perusahaan Perbankan Yang Terdaftar Di Bursa Efek Indonesia Periode 2016-2018. 2, 634-643.

Ristiani, R., \& Santoso, B. H. (2017). Pengaruh Tingkat Kesehatan Bank Terhadap Nilai Perusahaan Pada Bank-Bank Umum Yang Terdaftar DI BEI. Ijurnal Ilmu Dan Riset Manajemen, 3, 20.

Safitri, P. A., \& Hastutie, N. A. (2016). Pengaruh Tata Kelola Perusahaan Dan Kinerja Lingkungan Terhadap Nilai Perusahaan. Jurnal Akuntansi \& Keuangan Daerah, 11(2), 52-59.

Sianturi, M. W. E. (2020). Pengaruh Kinerja Keuangan Terhadap Nilai Perusahaan Manufaktur Sektor Industri Barang Konsumsi di BEI. EJournal Administrasi Bisnis, 8(4), 280-289.

Sunardi, N. (2019). Mekanisme Good Corporate Governance Terhadap Nilai Perusahaan Dengan Leverage Sebagai Variabel Intervening Pada Perusahaan Manufaktur Yang Terdaftar Di Bursa Efek Indonesia Tahun 2012-2018. JIMF (Jurnal Ilmiah Manajemen Forkamma), 2(3), 48-61.

Swarte, Wayan, Lindrianasari, Lindrianasari, Prasetyo, T. J., Sudrajat, S., \& Darma, F. (2020). Pengaruh Struktur Kepemilikan Dan Tata Kelola Perusahaan Terhadap Pengungkapan Manajemen Risiko. EKUITAS (Jurnal Ekonomi Dan Keuangan), 3(4), 505-523.

Triyuwono, EdwinNg, Suwandi, Daromes, \& Eduardus, F. (2020). Tata Kelola Perusahaan Sebagai Mekanisme Pengelolaan Risiko Untuk Meningkatkan Nilai Perusahaan. Media Riset Akuntansi, Auditing \& Informasi, 20(2), 205.

Wongso, A. (2013). Pengaruh Kebijakan Dividen, Struktur Kepemilikan, dan Kebijakan Hutang terhadap Nilai Perusahaan dalam Perspektif Teori Agensi dan Teori Agensi dan Teori Signaling. Jurnal Ilmiah Mahasiswa Manajemen, 1(5), 1-6. 